\title{
Filling the gaps in global antimicrobial resistance research/surveillance
}

\section{Luis Furuya-Kanamori ${ }^{*}$ and Laith Yakob ${ }^{2^{*}}$ (D)}

There is a large clinical and public health burden associated with antimicrobial resistance (AMR). This burden is likely to increase over time and urgent action is required $[1,2]$. In a recent review, it was estimated that AMR could cause 10 million deaths a year by 2050 [3]. However, there are major uncertainties associated with this estimate [4], not least of all the patchiness of surveillance data especially when it comes to developing countries.

A collection of new articles has been brought together in this special issue for BMC Infectious Diseases. This journal being an obvious hub for this type of research: being open access broadens the audience; and the board of committed, expert editors lends rigour to the science that is communicated. Emphasis has been placed on presenting latest results pertaining to AMR from around the world. Going to press, this special issue already has articles from a dozen countries spanning Latin America, Europe, West-to-East Africa, the Middle East, South and East Asia.

The criticality of surveillance in AMR is widely acknowledged and all of the articles of the special issue fall under this umbrella term, across very different scales, ranging from Irenge et al. [5] reporting on multidrugresistant (MDR) E. coli in local healthcare facilities in South Kivu province of the Democratic Republic of Congo to Galani et al. [6] reporting nationwide hospital carbapenem resistant K. pneumoniae survey for Greece.

Comprising one of the five strategic priorities of the Global Action Plan (GAP) on AMR [7], a recent report from the Interagency Coordination Group on Antimicrobial Resistance [8] describes several ways in which surveillance can support efforts to reduce AMR:

i) detect the emergence and prevalence of AMR e.g. Nelson et al. [9] developed a rapid cost-effective

\footnotetext{
* Correspondence: Luis.Furuya-Kanamori@anu.edu; laith.yakob@lshtm.ac.uk ${ }^{1}$ Research School of Population Health, Australia National University, Canberra, ACT, Australia

${ }^{2}$ Faculty of Infectious \& Tropical Diseases, London School of Hygiene \& Tropical Medicine, London, UK
}

molecular detection test for macrolide resistance that can be implemented in clinical settings. Surveillance studies at a national [6], regional [10], and local [5] level have exposed the magnitude of the AMR problem around the world.

ii) guide patient treatment e.g. Arevalo-Jaimes et al. [11] found 38\% of Colombian patients with $\mathrm{H}$. pylori were resistant to first line drug clarithromycin, calling into question the appropriateness of the current, standard triple therapy. Likewise, Mashe et al. [12] found that $88 \%$ of S. typhi in Zimbabwe were resistant to two or more first line drugs indicating the need for changes in their current guidelines.

iii) identify populations at risk e.g. Milovanovic et al. [13] found that more than half of patients with liver cirrhosis in Serbian tertiary care facilities that contracted hospital-acquired urinary tract infections were infected with MDR strains, calling for individualized protocols for treatment of these immunocompromised populations.

iv) inform policy development e.g. Haddad et al. [14] from the Lebanese Society of Infectious Diseases and Clinical Microbiology publish new guidelines for empiric and targeted antimicrobial therapy of complicated intra-abdominal infections based on risk factors, site of acquisition of infection, and clinical severity of illness.

v) assess the impact of interventions. Although there were many studies that investigated the current state of AMR to plan interventions, none described intervention effectiveness.

This being a rolling special issue, our coverage is expected to expand even further and continue spotlighting findings from regions of the world for which data are largely absent, and yet most necessary according to burden projections [3]. Given its conspicuous absence both from this special issue as well as the wider literature, we particularly encourage the submission of articles that assess AMR intervention effectiveness. 


\section{Acknowledgements}

We thank the authors of the studies published within this special issue; the editors and editorial staff that handled and processed these submissions; and the many independent reviewers for their time and effort in assessing these articles.

\section{Authors' contributions}

LY collated this special issue; both authors wrote the manuscript.

\section{Funding}

LFK is supported by an Australian National Health and Medical Research Council Fellowship (APP1158469). Funding bodies had no role in the design of the study and collection, analysis and interpretation of data nor in writing the manuscript.

\section{Ethics approval and consent to participate}

N/A.

\section{Availability of data and material}

N/A.

\section{Consent for publication}

N/A.

\section{Competing interests}

The authors declare that they have no competing interests.

Received: 23 July 2019 Accepted: 16 December 2019

Published online: 14 January 2020

\section{References}

1. de Kraker ME, Davey PG, Grundmann H. Mortality and hospital stay associated with resistant Staphylococcus aureus and Escherichia coli bacteremia: estimating the burden of antibiotic resistance in Europe. PLoS Med. 2011:8(10):e1001104.

2. Stewardson AJ, Allignol A, Beyersmann J, Graves N, Schumacher M, Meyer R, et al. The health and economic burden of bloodstream infections caused by antimicrobial-susceptible and non-susceptible Enterobacteriaceae and Staphylococcus aureus in European hospitals, 2010 and 2011: a multicentre retrospective cohort study. Euro Surveill. 2016;21(33)

3. O'Neil J. Antimicrobial resistance: tackling a crisis for the health and wealth of nations. 2014. https://amr-review.org/sites/default/files/AMR\%20Review\%2 OPaper\%20-\%20Tackling\%20a\%20crisis\%20for\%20the\%20health\%20and\%2 Owealth\%20of\%20nations_1.pdf

4. de Kraker ME, Stewardson AJ, Harbarth S. Will 10 million people die a year due to antimicrobial resistance by 2050? PLoS Med. 2016;13(11):e1002184.

5. Irenge LM, Ambroise J, Bearzatto B, Durant J-F, Chirimwami RB, Gala J-L. Whole-genome sequences of multidrug-resistant Escherichia coli in SouthKivu Province, Democratic Republic of Congo: characterization of phylogenomic changes, virulence and resistance genes. BMC Infect Dis. 2019;19(1):137

6. Galani I, Nafplioti K, Adamou P, Karaiskos I, Giamarellou H, Souli M. Nationwide epidemiology of carbapenem resistant Klebsiella pneumoniae isolates from Greek hospitals, with regards to plazomicin and aminoglycoside resistance. BMC Infect Dis. 2019;19(1):167.

7. World Health Organization. Global action plan on antimicrobial resistance. Geneva: World Health Organization; 2015. http://www.who.int/antimicrobialresistance/global-action-plan/en/

8. Interagency Coordination Group on Antimicrobial Resistance. Surveillance and monitoring for antimicrobial use and resistance. 2018. https:/www. who.int/antimicrobial-resistance/interagency-coordination-group/IACG_ Surveillance_and_Monitoring_for_AMU_and_AMR_110618.pdf?ua=1

9. Nelson MM, Waldron CL, Bracht JR. Rapid molecular detection of macrolide resistance. BMC Infect Dis. 2019;19(1):144.

10. Ouchar Mahamat O, Lounnas M, Hide M, Dumont $Y$, Tidjani A, Kamougam $\mathrm{K}$, et al. High prevalence and characterization of extended-spectrum sslactamase producing Enterobacteriaceae in Chadian hospitals. BMC Infect Dis. 2019:19(1):205

11. Arevalo-Jaimes BV, Rojas-Rengifo DF, Jaramillo CA, de Molano BM, VeraChamorro JF, Del Pilar Delgado M. Genotypic determination of resistance and heteroresistance to clarithromycin in Helicobacter pylori isolates from antrum and corpus of Colombian symptomatic patients. BMC Infect Dis. 2019;19(1):546.

12. Mashe T, Gudza-Mugabe M, Tarupiwa A, Munemo E, Mtapuri-Zinyowera S, Smouse SL, et al. Laboratory characterisation of Salmonella enterica serotype Typhi isolates from Zimbabwe, 2009-2017. BMC Infect Dis. 2019; 19(1):487.

13. Milovanovic T, Dumic I, Velickovic J, Lalosevic MS, Nikolic V, Palibrk I. Epidemiology and risk factors for multi-drug resistant hospital-acquired urinary tract infection in patients with liver cirrhosis: single center experience in Serbia. BMC Infect Dis. 2019;19(1):141.

14. Haddad N, Kanj SS, Awad LS, Abdallah DI, Moghnieh RA. The 2018 Lebanese Society of Infectious Diseases and Clinical Microbiology Guidelines for the use of antimicrobial therapy in complicated intraabdominal infections in the era of antimicrobial resistance. BMC Infect Dis. 2019;19(1):293.

\section{Publisher's Note}

Springer Nature remains neutral with regard to jurisdictional claims in published maps and institutional affiliations.

\section{Ready to submit your research? Choose BMC and benefit from:}

- fast, convenient online submission

- thorough peer review by experienced researchers in your field

- rapid publication on acceptance

- support for research data, including large and complex data types

- gold Open Access which fosters wider collaboration and increased citations

- maximum visibility for your research: over $100 \mathrm{M}$ website views per year

At BMC, research is always in progress.

Learn more biomedcentral.com/submissions 